BDX-613-887 (Rev.)

REMOVAL OF INSULATION FROM MULTICONDUCTOR WIRE TAPE USING A CARBON DIOXIDE LASER

PDO 6984790, Topical Report

R. T. Horn, Project Leader

Published May 1974

Prepared for the United States Atomic Energy Commission Under Contract Number AT(29-1)-613 USAEC
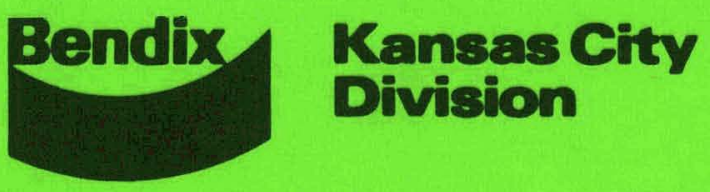


\section{DISCLAIMER}

This report was prepared as an account of work sponsored by an agency of the United States Government. Neither the United States Government nor any agency Thereof, nor any of their employees, makes any warranty, express or implied, or assumes any legal liability or responsibility for the accuracy, completeness, or usefulness of any information, apparatus, product, or process disclosed, or represents that its use would not infringe privately owned rights. Reference herein to any specific commercial product, process, or service by trade name, trademark, manufacturer, or otherwise does not necessarily constitute or imply its endorsement, recommendation, or favoring by the United States Government or any agency thereof. The views and opinions of authors expressed herein do not necessarily state or reflect those of the United States Government or any agency thereof. 


\section{DISCLAIMER}

Portions of this document may be illegible in electronic image products. Images are produced from the best available original document. 
REMOVAL OF INSULATION FROM MULTICONDUCTOR WIRE TAPE USING A CARBON DIOXIDE LASER

BDX-613-887 (Rev.)

Published May 1974

Project Leader:

R. T. Horn

Department 812

PDO 6984790

Topical Keport
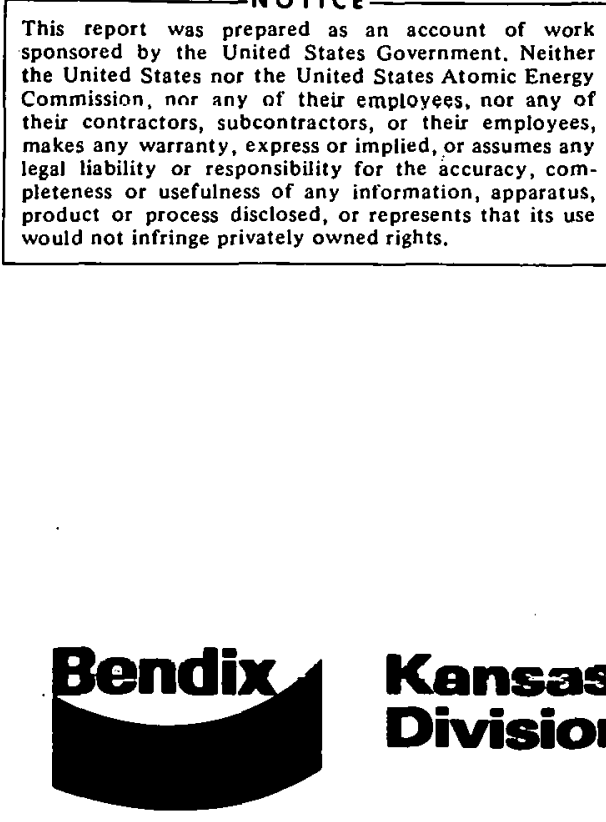
THIS PAGE

WAS INTENTIONALLY

LEFT BLANK 


\title{
REMOVAL OF INSULATION FROM MULTICONDUCTOR WIRE TAPE USING A CARBON DIOXIDE LASER
}

\author{
BDX-613-887 (Rev.), UNCLASSIFIED Topical Report, Published. \\ May 1974
}

Prepared by R. T. Horn, D/812, under PDO 6984790.

Use of a carbon dioxide laser for removing insulation from multiconductor wire tape was investigated. A process to remove insulation from single wires was developed. Microscopic examination and emission spectrographs were used to evaluate process results.

This report was prepared as an account of work sponsored by the United States Government. Neither the United States nor the United States Atomic Energy Commission, nor any of their employees, nor any of their contractors, subcontractors, or their employees, makes any warranty, express or implied, or assumes any legal liability or responsibility for the accuracy, completeness or usefulness of any information, apparatus, product or process disclosed, or represents that its use would not infringo privately owned rights.
THE BENDIX CORPORATION

KANSAS CITY DIVISION

KANSAS CITY, MISSOURI

A prime contractor for the Atnmic Enerov Commission

Contract Number AT(29-1)-613 USAEC 
THIS PAGE

\section{WAS INTENTIONALLY LEFT BLANK}




\section{CONTENTS}

Section

Page

SUMMARY . . . . . . . . . . . . . . . . . . .

DISCUSSION . . . . . . . . . . . . . . . . . .

SCOPE AND PURPOSE . . . . . . . . . . . . . . .

PRIOR WORK . . . . . . . . . . . . . . . .

ACTIVITY . . . . . . . . . . . . . . . . . .

TEA Laser • . . . . . . . . . . . . . . .

Conventional $\mathrm{CO}_{2}$ Laser . . . . . . . . . . . . . . .

Apollo $\mathrm{CO}_{2}$ Laser . . . . . . . . . . . . . . . . . .

ACCOMPLISHMENTS • . • . . • . • . . . . • . . 26

FUTURE WORK •. . . . . . . . . . . . . . . .

REFERENCES . . . . . . . . . . . . . . . . . . 
THIS PAGE

\section{WAS INTENTIONALLY LEFT BLANK}




\section{ILLUSTRATIONS}

Figure

Page

1 Section of 90 Number 33-AWG Insulated Copper Magnet Wires Laid Side by Side, With Nylon Fibers Interwoven to Form a Tape (P80865). . . . . . . . . . . .

Cross Section of Individual Number 33-AWG Copper

Magnet Wire With Polythermalize 200 Insulation . . . .

TEA (Transversely Excited at Atmospheric Pressure)

$\mathrm{CO}_{2}$ Laser at Bendix Research Laboratories. . . . . .

Unfocused Energy Density Pattern of Cross Section of Bendix Research Laboratories TEA $\mathrm{CO}_{2}$ Laser Beam. . .

Epon-Coated Copper Sheets Used to Determine Focused Energy Density Pattern of Bendix Research Laboratories TEA $\mathrm{CO}_{2}$ Laser Beam (Polaroid). . . . . . . . .

Conventional Longitudinal Electric Discharge $\mathrm{CO}_{2}$ Laser . . . . . . . . . . . . . . . . . .

Intensity Cross Section of a Fundamental Gaussian Beam • •

Copper Wires After Laser Scanning (P74506) . . . . . .

Laser-Scanned Numher 33-AWr Cnpper Wires. Tinned With 63 Percent Tin-37 Percent Lead Solder (P74295).

Copper Wires Severed by Laser Scanning (Polaroid) • . •

11 Black Char Produced From Insulation on Copper Magnet Wire by Laser Scanning, 60X (Polaroid). . . . . . . .

12 Mass Spectrograph Mlustrating Insulation Remaining on Copper Magnet Wire After Laser Scanning. . . . . . . 
15 Cross Section of Number 33-AWG Copper Wire and Insulation System, Showing Amount of Insulation Removed . . . . . . . . . . . . . . .

\section{TABLE}

Number Page

1 Parameters Recorded During $\mathrm{CO}_{2}$ Laser Processing of Multiconductor Wire Tape at a Laser Vendor Facility. . 


\section{SUMMARY}

Removing dielectric material from multiconductor wire tape with a carbon dioxide $\left(\mathrm{CO}_{2}\right)$ laser was investigated.

The multiconductor wire tape consists of 90 number 33-AWG insulated copper magnet wires laid side by side and held together with nylon fibers interwoven to form a flat tape. Each wire is 0.0071-inch-diameter $(0.18 \mathrm{~mm}$ ) annealed copper, coated with a 0.00072 -inch-thick $(0.018 \mathrm{~mm})$ layer of polyethylene terephthalate cross-linked with an isocyanate and then coated with a 0.00008 inch-thick $(0.002 \mathrm{~mm})$ layer of linear polyethylene terephthalate (Polythermaleze 200). Insulation is to be removed from 0.300 inch $(7.62 \mathrm{~mm}$ ) along each wire to permit tinning for subsequent electrical connection.

Three lasers were investigated for this purpose. The first was a TEA (transversely excited at atmospheric pressure) $\mathrm{CO}_{2}$ laser. This laser had sufficient power to remove irregularaly-shaped pieces of insulation, but the tooling setup used did not permit precision scanning of the sample. Samples suitable for tinning were not produced.

The second laser investigated was a conventional longitudinal-discharge $\mathrm{CO}_{2}$ laser made available by a vendor. This laser was operated in both pulsed and continuous modes to determine optimum effects. Insulation was successfully removed when the laser was operated at 50 watts continuous output power and the wire was scanned at 6 inches $/ \mathrm{second}(150 \mathrm{~mm} / \mathrm{sec})$.

The third laser investigated was a conventional longitudinal discharge $\mathrm{CO}_{2}$ laser located at Bendix Kansas City. With suitable tooling which made possible high speed repeatable scanning, wires were successfully stripped at a scan rate of 6 inches/second and 50 watts continuous output power.

It was also discovered that, under certain conditions, the process uses reflection within the insulation during scanning of the wires on one side to remove the insulation from $235^{\circ}$ of the wire circumference.

Microscopic inspections, mass spectrographs, and susceptibility to tinning were used to determine the effectiveness of the removal process. In some cases, it was noted that wires which appeared completely clean under microscopic inspection had a layer of insulation that appeared only in a. mass spectrograph of the sample and prevented successful tinning. 
THIS PAGE

\section{WAS INTENTIONALLY LEFT BLANK}




\section{DISCUSSION}

\section{SCOPE AND PURPOSE}

The purpose of this work was to develop an insulation removal process applicable to multiconductor wire tape assemblies as an alternative to chemical removal methods. This activity involved the investigation of equipment for removal of insulation from the wire used in the tape. Parameters such as scan speed, laser power level, and effective focused spot size were investigated.

This work is in support of current weapon fabrication at Bendix. Concurrent study on the curved Mod 93 Tile Cover is in progress and will be covered in a later report. The work reported here was accomplished between August 1971 and February 1973 and was supported by Process Development Order 6984790, Laser Applications.

\section{PRIOR WORK}

The investigation of carbon dioxide lasers for insulation removal began at Bendix some time ago. A process has been developed to remove dielectric from flat cables. ${ }^{1}$ Many of the principles developed for that process are applicable to this work.

\section{ACTIVITY}

The use of carbon dioxide $\left(\mathrm{CO}_{2}\right)$ lasers to remove insulation from multiconductor wire tape was investigated. This wire tape consists of 90 number 33 AWG insulated copper magnet wires laid side by side with nylon fibers interwoven to form the tape (Figure 1). Each wire consists of 0.0071-inchdiameter $(0.18 \mathrm{~mm})$ annealed copper coated with a 0.00072 -inch-thick $(0.018 \mathrm{~mm})$ layer of polyethylene terephthalate cross-linked with an isocyanate and then coated with a 0.00008 -inch-thick $(0.002 \mathrm{~mm})$ layer of linear polyethylene terephthalate (Polythermaleze 200). A cross section of an individual wire is shown in Figure 2. Insulation must be removed for 0.3 inch $(8 \mathrm{~mm})$ along each wire to permit tinning for subsequent electrical connection. To achieve this purpose, three lasers were investigated.

\section{TEA Laser}

Initial investigations were conducted with a TEA (transversely excited at atmospheric pressure) $\mathrm{CO}_{2}$ laser located at Bendix Research Laboratories 


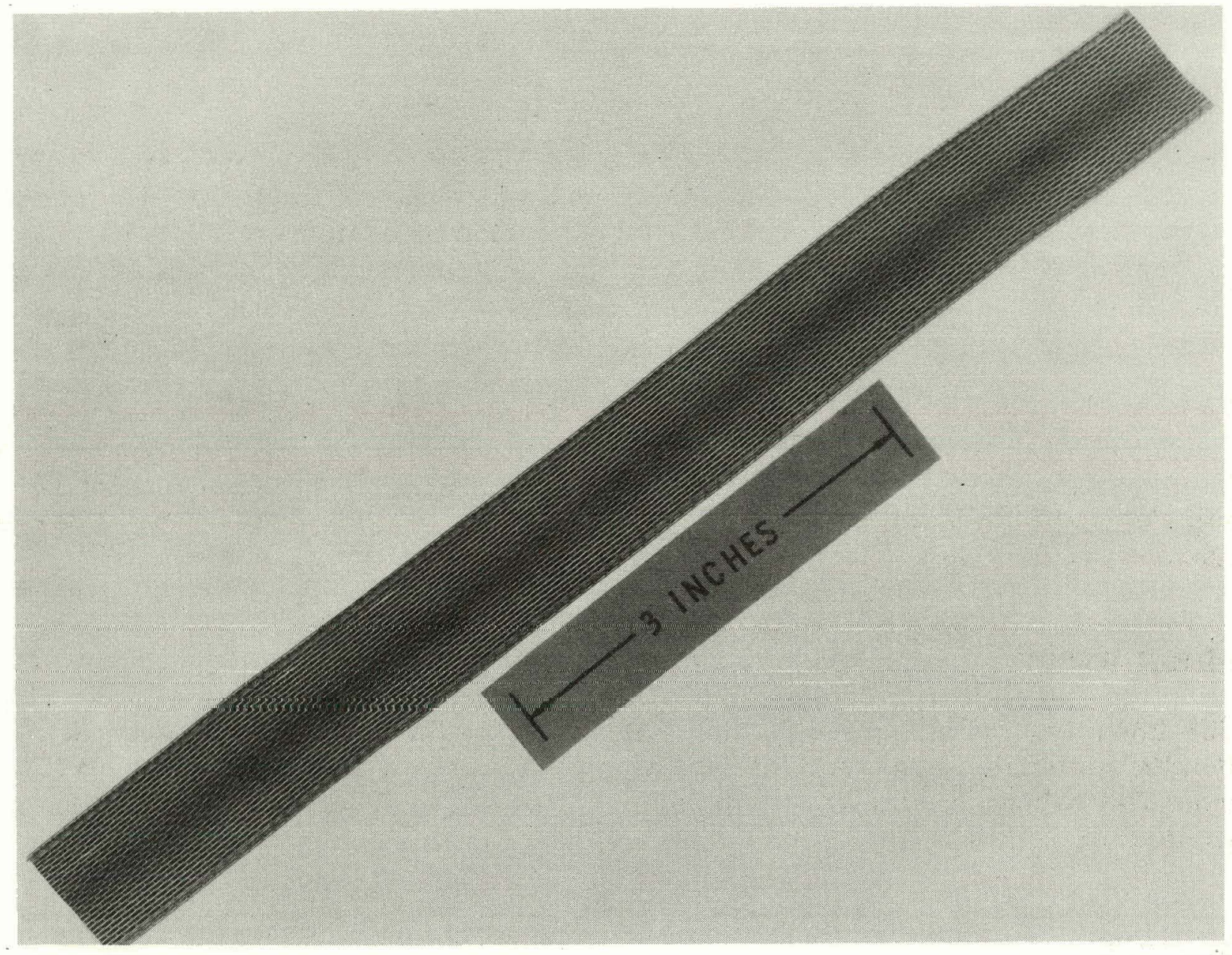

Figure 1. Section of 90 Number 33-AWG Insulated Copper Magnet Wires Laid Side by Side, With Nylon Fibers Interwoven to Form a Tape

(BRL) Ann Arbor, Michigan. This laser is relatively basic in construction (Figure 3 ) and has a peak output power of 1 megawatt at a pulse repetition rate from 0 to 30 pulses per second. The pulse length is 2.0 microseconds, and 0.2 joules of energy is delivered in each pulse. From this information the average output power can be calculated.

Average power $=$ repetition rate $\mathrm{x}$ energy per pulse $=\frac{30 \text { pulses }}{\mathrm{sec}} \times \frac{0.2 \text { joules }}{\text { pulse }}$

$$
=\frac{6 \text { joules }}{\mathrm{sec}} \text { or } 6 \text { watts }
$$




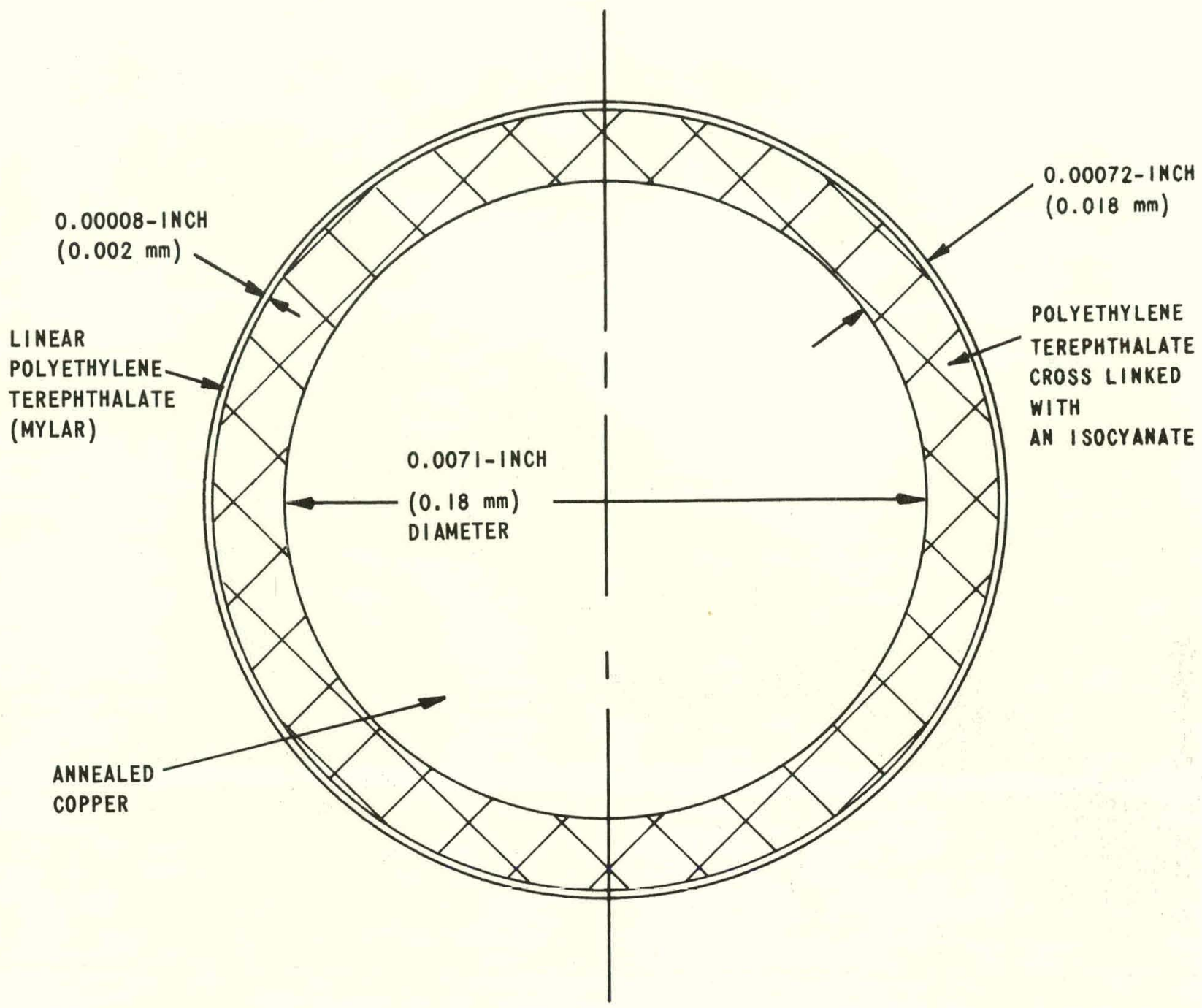

Figure 2. Cross Section of Individual Number 33-AWG Copper Magnet Wire With Polythermaleze 200 Insulation

An important point to consider is that the energy in a laser beam is not evenly distributed across a given cross section of the beam perpendicular to its axis.

This energy distribution or cross-sectional energy density is determined by the resonant ravity that generates the beam. For this particular laser, the energy density appeared as three circles side by side (Figure 4). This is the energy density before focusing. If a spherical lens is used, as was the case with this laser, the energy density retains the same pattern across the focused spot. Epon-coated copper sheets were used to determine the cross-sectional energy density pattern of this laser (Figure 5). This type energy density pattcrn is difficult to apply to uniform insulation removal when the area to 


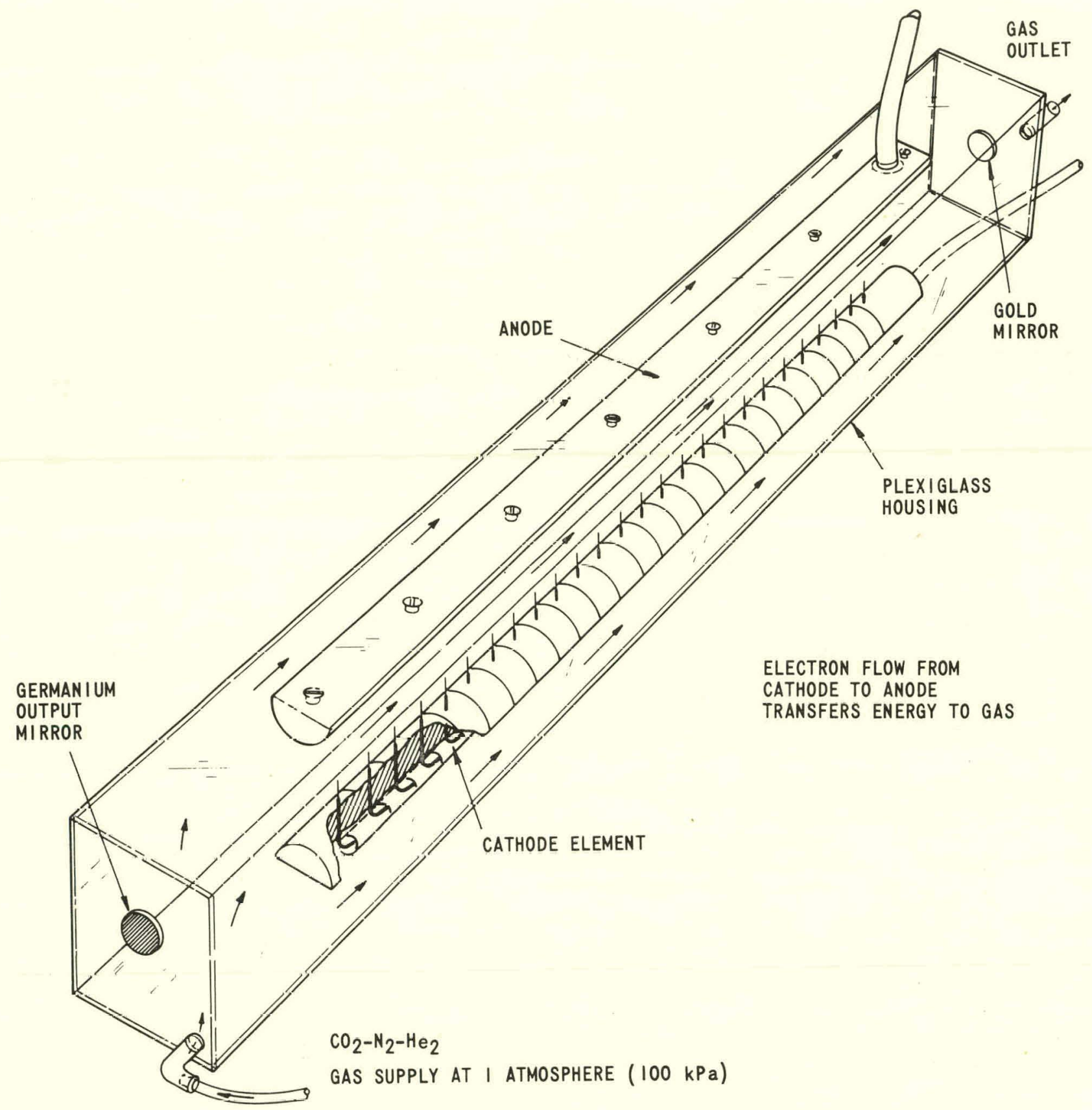

Figure 3. TEA (Transversely Excited at Atmospheric Pressure) $\mathrm{CO}_{2}$ Laser at Bendix Research Laboratories 


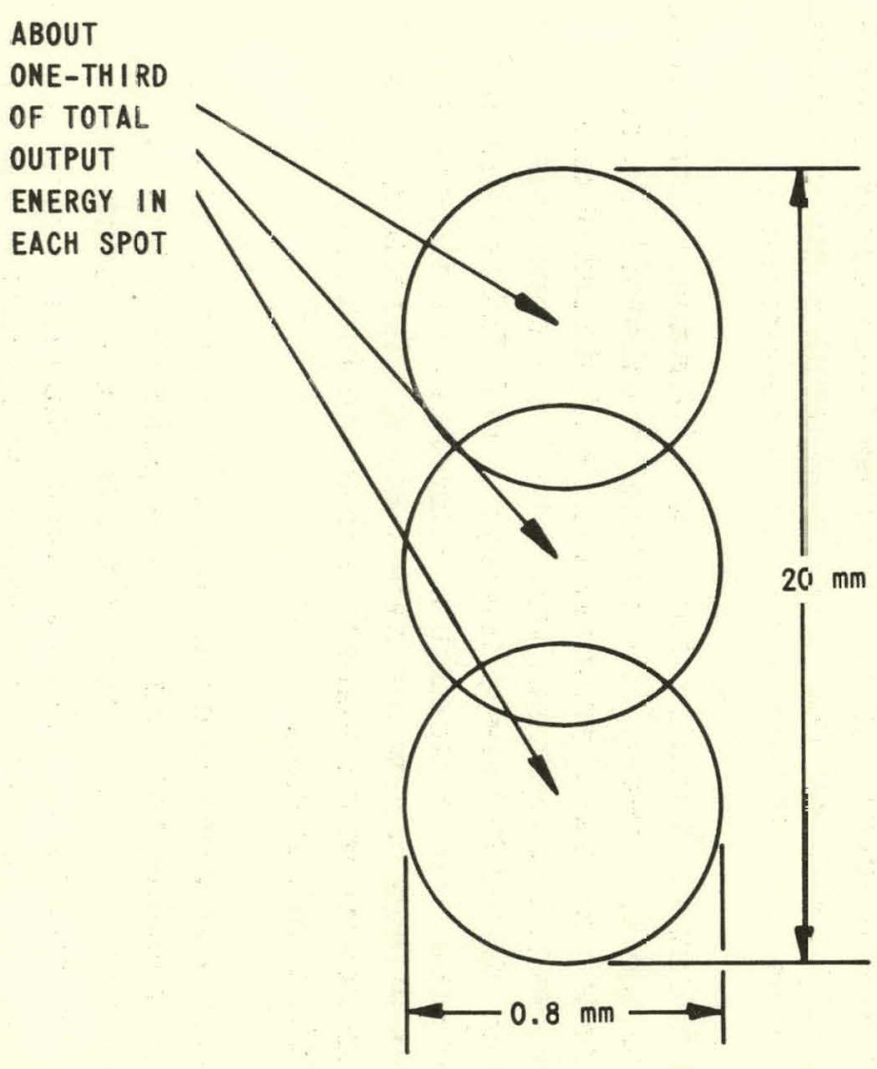

Figure 4. Unfocused Energy Density Pattern of Cross Section of Bendix Research Laboratories TEA $\mathrm{CO}_{2}$ Laser Beam

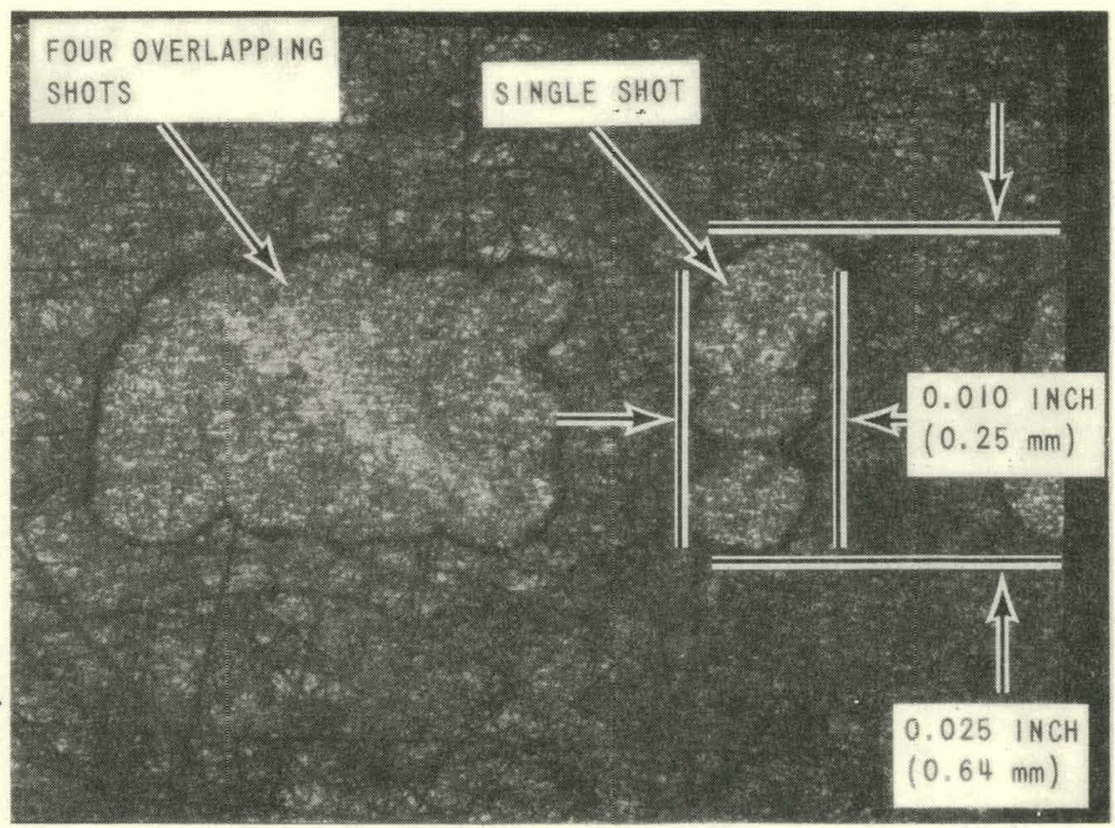

Figure 5. Epon-Coated Copper Sheets Used to Determine Focused Energy Density Pattern of Bendix Research Laboratories TEA $\mathrm{CO}_{2}$ Laser Beam 
be exposed is on the same order of size as the focused spot. It is also known that the focal depth of such a pattern is very short, ${ }^{2}$ and multiple precision scanning would be required to remove dielectric from an area large enough to examine or tin. With the setup provided at BRL, the samples of multiconductor wire tape had to be hand held and passed through what was thought to be the focal point of the lens. Microscopic examination of the sample exposed revealed that irregular-shaped sections of the insulation had apparently been removed. These sections, though apparently clean, did not overlap enough to provide suitable area for successful tinning of the wires by dipping them in a solder pot full of 63 percent tin 37 percent lead solder. With further development of repition rates over 1000 per second and improvements in beam energy distribution, this laser could be used for insulation remnval,

The tests revealed that the $\mathrm{CO}_{2}$ laser would remove dielectric material from magnet wires, and it was concluded that the use of a $\mathrm{CO}_{2}$ laser for this purpnse warranted further study. It was also concluded that, without major modification, the features of this specific laser and its support fixturing were not suited for this application.

\section{$\underline{\text { Conventional } \mathrm{CO}_{2} \text { Laser }}$}

The second laser investigated was a commercial $\mathrm{CO}_{2}$ unit at Coherant Radiation Company. This laser uses a longitudinal electrical discharge to excite the gas (Figure 6) and has the capability of having a continuous nutput. of 50 watts, or a pulsed peak power of up to 1000 watts. The resonant cavity of this laser has been adjusted so that the cross-sectional energy density of the beam approximates a gaussian curve (Figure 7). This type energy distribution allows focusing to smaller spots with greater focal depth than any other. It is therefore said that the laser is operating in the fundamental mode. 3

Samples were prepared from sections of multiconductor wire tape. They were mounted on a positioning system that allowed a complete tape sample to be driven across the focused spot of the beam and then manually indexed and driven back through the beam again. The speed with which the tape was driven through the beam was recorded but the equipment used did not permit the amount of indexing between scans to be measured and repeatibility was governed only by trying to turn a lead screw the same amount for each pass. It appears from subsequent microscopic examination that the indexing was on the order of 0.006 inch $(0.15 \mathrm{~mm})$ or less.

Several drive speeds and power levels were used (Table 1). Some samples were processed with the laser in pulse operation with a repetition rate of 200 pulses per second, a peak power of 125 watts, and a scanning rate of $0.5 \mathrm{inch} / \mathrm{second}(13 \mathrm{~mm} / \mathrm{sec})$. Microscopic examination of these samples revealed areas where the laser had either not removed the insulation or the 


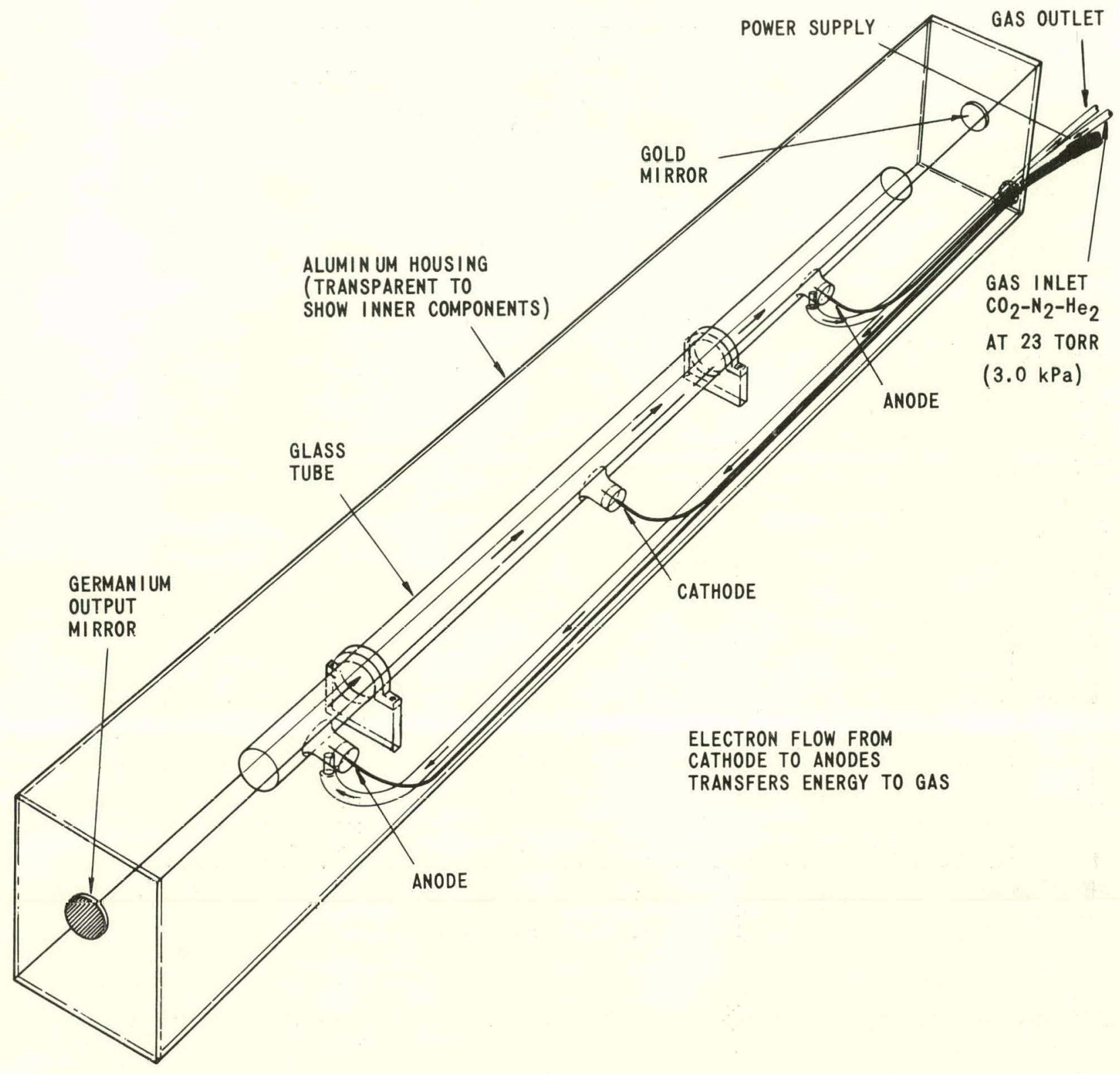

Figure 6. Conventional Longitudinal Electrical Discharge $\mathrm{CO}_{2}$ Laser

material vapor had redeposited on the surface of the wire. Some samples were processed with the laser in pulse operation with a repetition rate of 9600 pulses per second, a peak power of 1458 watts, and a scanning rate of 0.5 inch per second. Microscopic examination of these samples revealed a more complete job of insulation removal with fewer spots of insulation remaining on the wires. Samples that were processed with the laser in 


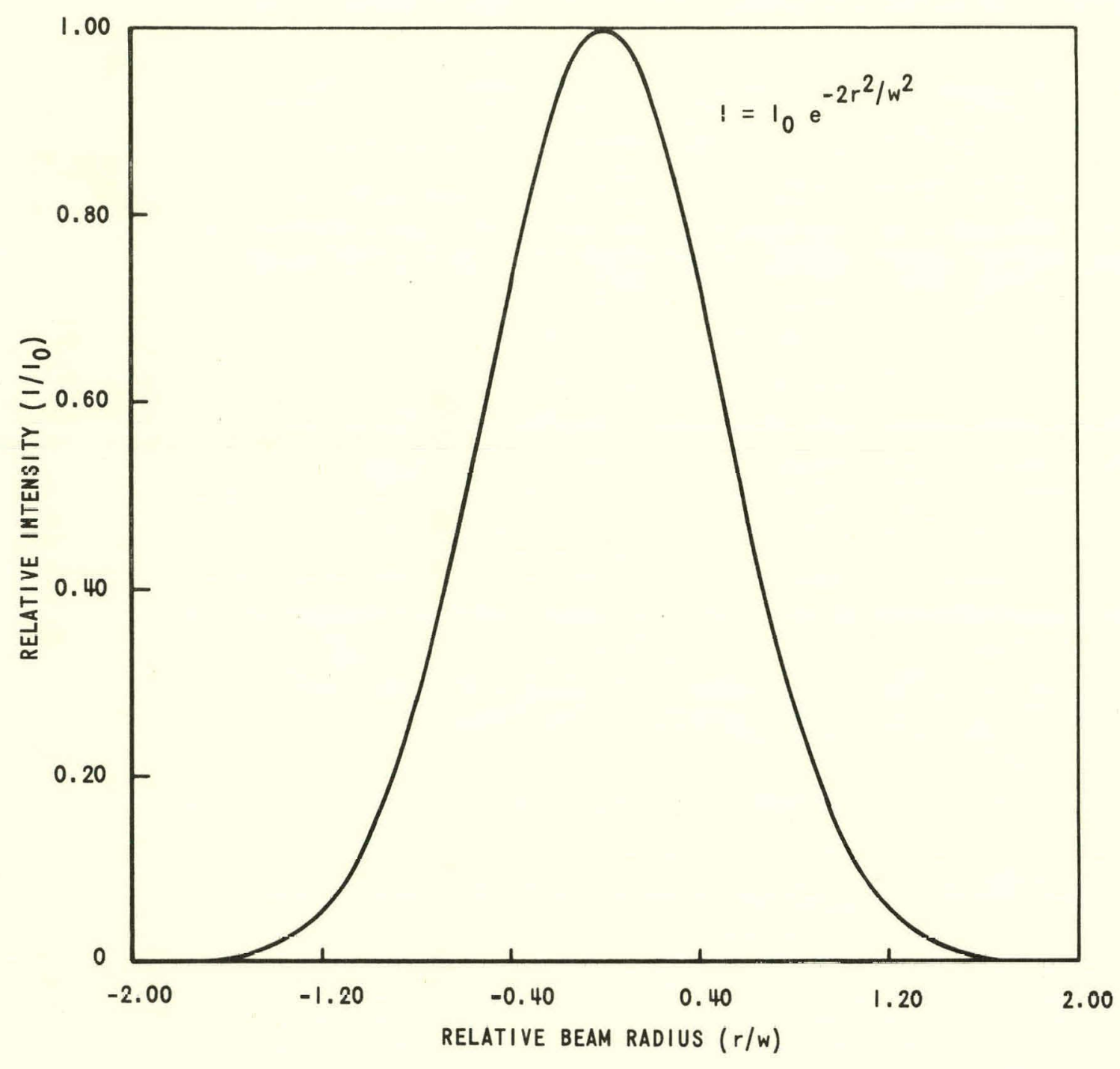

Figure 7. Intensity Cross Section of a Fundamental Gaussian Beam

continuous operation at 50 watts output were scanned at 6 inches/second $(150 \mathrm{~mm} / \mathrm{sec})$. These samples appeared the cleanest of all and were capable of being tinned with 63 percent tin 37 percent lead solder (Figures 8 and 9). All samples were scanned on each side $180^{\circ}$ apart.

The tests conducted with the Coherant Radiation laser revealed that a commercially-available $\mathrm{CO}_{2}$ laser was satisfactory for removing insulation from magnet wires and other dielectrics from other metallic cables. Bendix then procured an Apollo $\mathrm{CO}_{2}$ laser for this purpose. 
Table 1. Parameters Recorded During $\mathrm{CO}_{2}$ Laser Processing of Multiconductor Wire Tape at a Laser Vendor Facility

\begin{tabular}{|c|c|c|c|c|c|c|c|c|c|}
\hline Sample & $\begin{array}{l}\text { Scan Rate } \\
\text { (Inches/Second) }\end{array}$ & $\begin{array}{l}\text { Pulse I.ength } \\
(0.001 \mathrm{sec})\end{array}$ & $\begin{array}{l}\text { Pulse Repetition } \\
\text { Rate } \\
\text { (P'ulses per Second) }\end{array}$ & $\begin{array}{l}\text { Peak } \\
\text { Pulse Power } \\
\text { (Watts): }\end{array}$ & $\begin{array}{l}\text { Average } \\
\text { Power } \\
\text { (Watts) }\end{array}$ & $\begin{array}{l}\text { Foc:al Spot } \\
\text { Diameter } \\
\text { (Inch) }\end{array}$ & $\begin{array}{l}\text { Number of } \\
\text { Passes Before } \\
\text { Indexing }\end{array}$ & $\begin{array}{l}\text { Type of Gas } \\
\text { Blowing Across } \\
\text { Part to Carry } \\
\text { Away Material } \\
\text { Vapor }\end{array}$ & $\begin{array}{l}\text { Solution lised } \\
\text { To Clean Wires } \\
\text { Azter Processing }\end{array}$ \\
\hline 1 & 0.5 & 0.6 & 200 & 125 & 15 & 0.006 & 2 & Filtered Air & Trichloroethylene \\
\hline 2 & 0.5 & 0.6 & 200 & 125 & 15 & 0.006 & 2 & Nitrogen & Trichloroethy lene \\
\hline 3 & 0.5 & 0.6 & 200 & 125 & 15 & 0.006 & 1 & Nitrogen & Trichloroethylene \\
\hline 4 & 0.5 & 0.005 & $! 1600$ & 1458 & 7 & 0.006 & 2 & Nitrogen & Trichlorocthylene \\
\hline 5 & is & $\cdots$ & $-\cdots$ & $\cdots-$ & 50 & 0.006 & 1 & Nitrogen & Trichloroethylene \\
\hline 6 & is & $\ldots$ & $-\cdots$ & $\cdots$ & 50 & 0.006 & 1 & Nitrogen & Methanol \\
\hline 7 & : & $-\ldots-$ & $-\cdots$ & -..- & 50 & 0.008 & 1 & Nitrogen & Trichloroethy lene \\
\hline 8 & 4 & 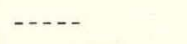 & $-\cdots$ & $-\cdots$ & 50 & 0.008 & 1 & Nitrogen & Trichloroethylene \\
\hline \multicolumn{10}{|c|}{1} \\
\hline
\end{tabular}




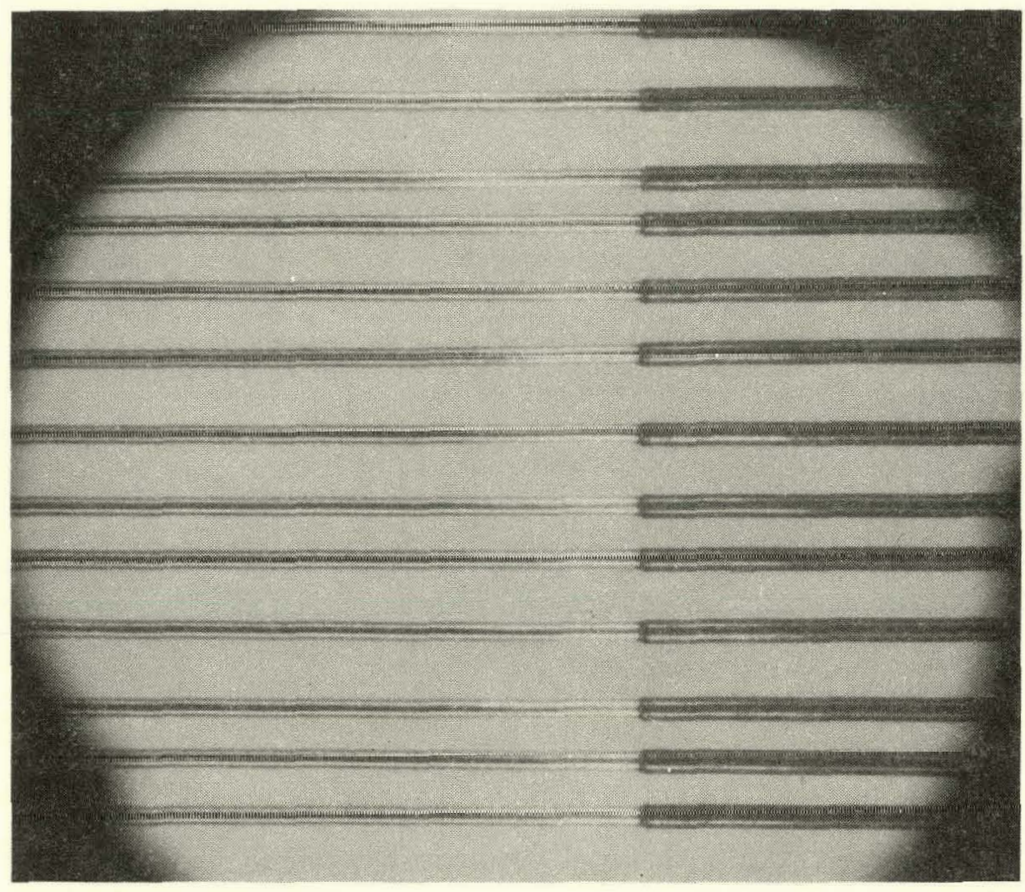
NUMBER 33-AWO COPPER WIRE
6 INCHES/SECOND (150 mm/SEC)
SCAN SPEED
50 WATTS $\mathrm{CO}_{2}$ LASER OUTPUT POWER
$0.006-I N C H-D I$ AMETER $(0.15 \mathrm{~mm})$
FOCAL SPOT

Figure 8. Copper Wires After Laser Scanning

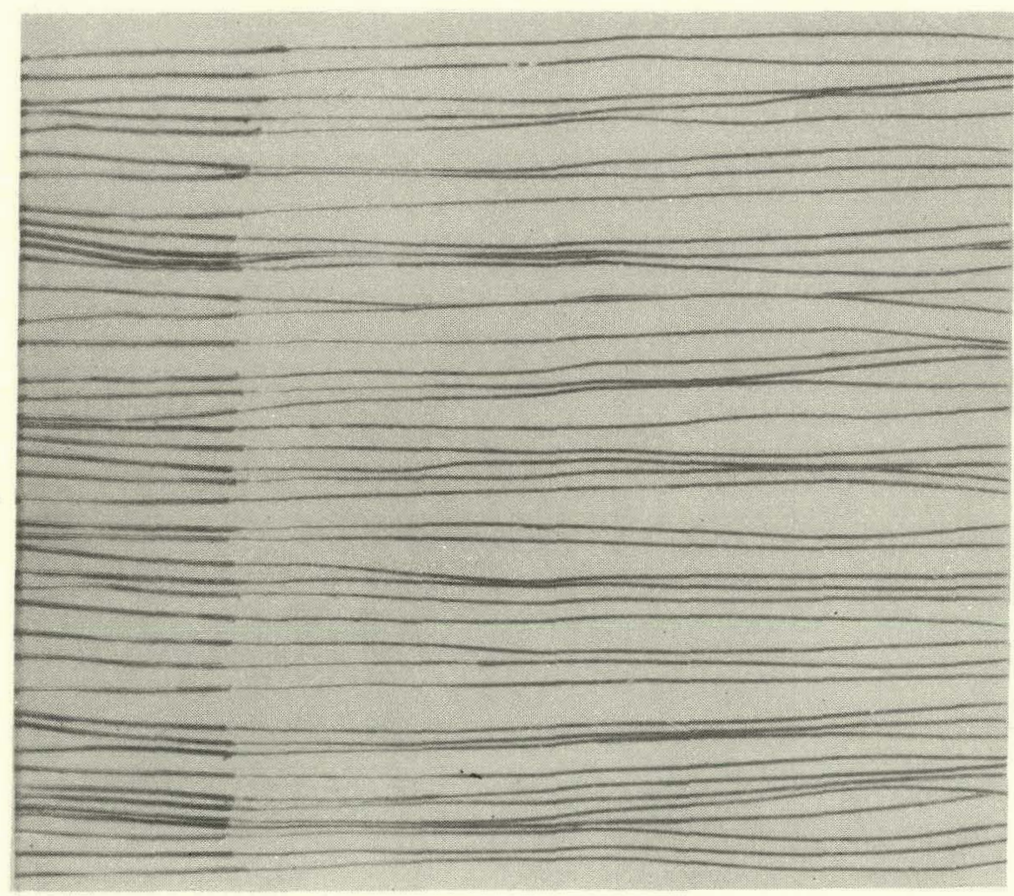

Figure 9. Laser-Scanned Number 33-AWG Copper Wires, Tinned With 63 Percent Tin-37 Percent Lead Solder 
$\underline{\text { Apollo } \mathrm{CO}_{2} \text { Laser }}$

The Apollo Lasers, Inc., Model $500 \mathrm{CO}_{2}$ laser located at Bendix uses a longitudinal electrical discharge to excite the gas (Figure 6) and has the capability of operating at 50 watts of continuous output power or a pulsed peak power up to 300 watts. The cross-sectional energy density of the output beam is gaussian.

Samples processed at the original maximum speed of 3 inches/second $(80 \mathrm{~mm})$ and 50 watts of continuous power focused to a 0.005 -inch-diameter $(0.13 \mathrm{~mm}$ ) focal spot were severed (Figure 10).

Samples processed at the same speed and focal spot size but at 40 watts continuous power appeared covered with a fine black char (Figure 11). This char could be removed by vigorous cleaning with alcohol. Microscopic inspection revealed apparently clean wire, but tinning attempts were unsuccessful. Mass spectrographs revealed a layer of insulation remaining on the wire (Figure 12).

Tooling was developed that made possible traverse speeds up to 13 inches/ second $(330 \mathrm{~mm} / \mathrm{sec})$. This tooling consists of a drum that is rotated about its axis under the focused spot of the laser. Each revolution of the drum trips a microswitch which causes the drum to be moved 0.002 inch $(0.050 \mathrm{~mm})$ parallel to its axis.

The effect of passing the wire through the focused spot of the laser beam at 6 inches/second was examined. The effective focused spot size that crossed the wire was approximately 0.005 inch $(0.13 \mathrm{~mm}$ ) in diameter (Figure 13). A microscopic examination of the side of the wire opposite the exposure revealed that areas of insulation not in the direct path of the laser beam were affected (Figure 14). From the photomicrograph, it was determined that the shortest surface distance between the areas affected was 0.0031 inch $(0.079$ $\mathrm{mm}$ ). By dividing this value by the circumference of the outer insulation and then multiplying the result by $360^{\circ}$, the amount of insulation unaffected can be determined.

$\frac{0.0031 \times 360^{\circ}}{\pi(0.0079)} \approx 45^{\circ}$

By graphically plotting this on a cross section view of the wire and then plotting the maximum penetration of a beam reflected off the inside of the outer insulation (Figure 15) it can be seen that internal reflection can account for the additional insulation removal.

Text continued on page 26 . 


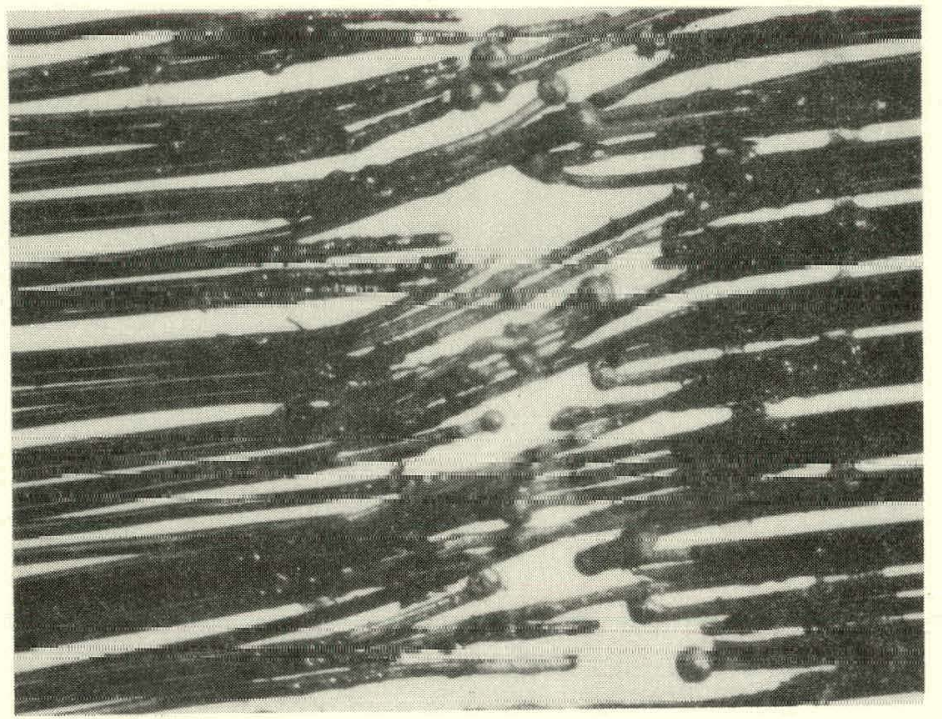

Figure 10. Copper Wires Severed by Laser Scanning

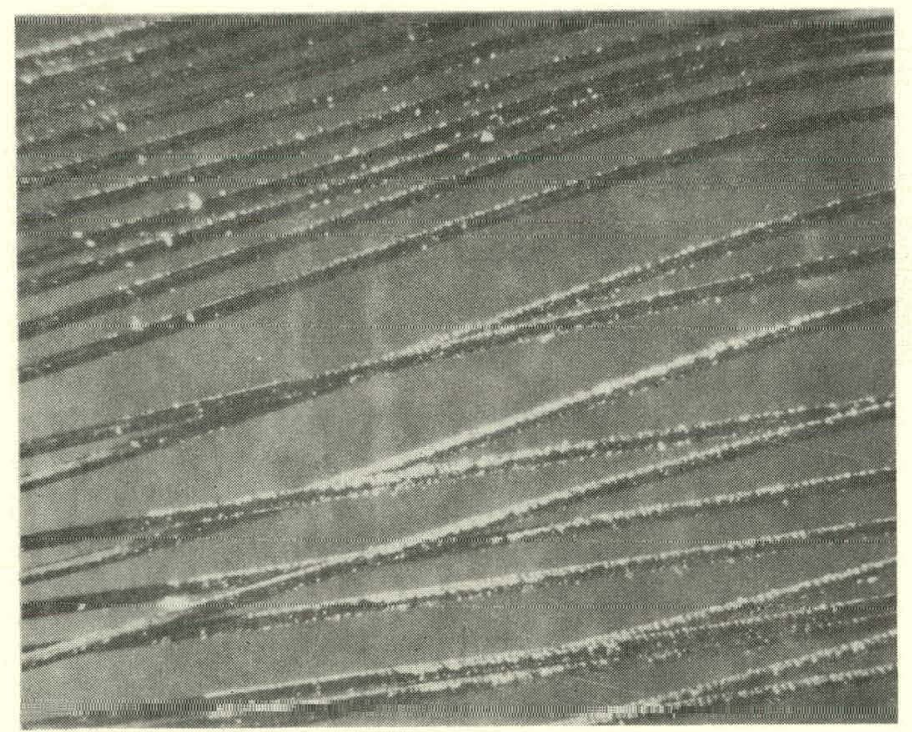

NUMBER 33-AWG COPPER WIRE

3 INCHES/SECOND $(75 \mathrm{~mm} / \mathrm{SEC})$ SCAN SPEED

40 WATTS LASER OUTPUT POWER

0.005 - INCH-DIAMETER $(0.13 \mathrm{~mm})$ FOCAL SPOT

Figure 11. Black Char Produced From Insulation on Copper Magnet Wire by Laser Scanning, $60 \mathrm{X}$ 

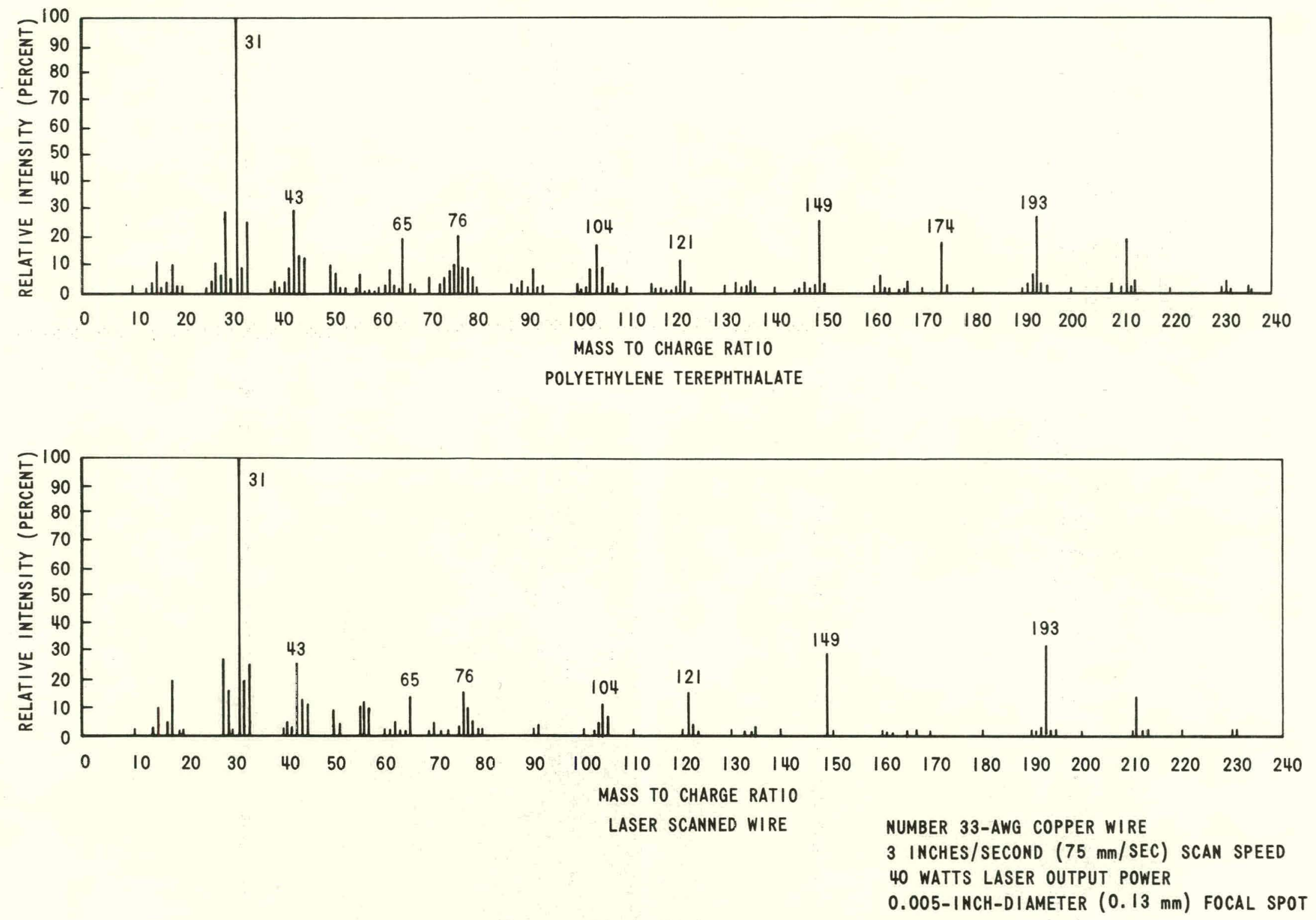

Figure 12. Mass Spectrograph nlustrating Insulation Remaining on Copper Magnet Wire After Laser Scanning 


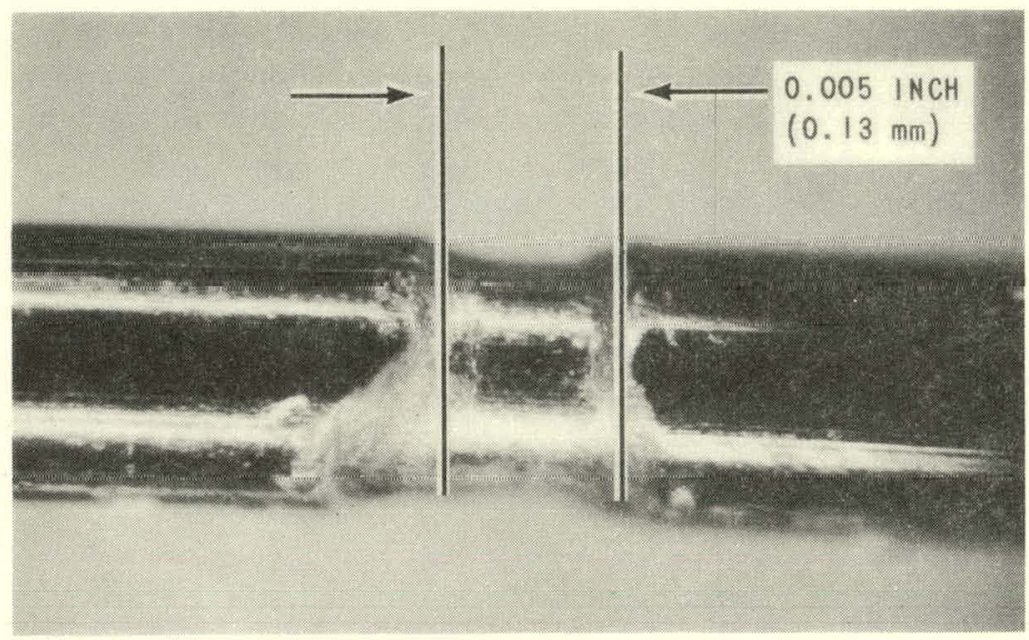

\author{
NUMBER 33-AWG COPPER WIRE \\ 6 INCHES/SECOND ( $150 \mathrm{~mm} / \mathrm{SEC})$ \\ SCAN SPEED \\ 50 WATTS LASER OUTPIIT POWFR \\ $0.005-I$ NCH-DIAMETER $(0.13 \mathrm{~mm})$ \\ FOCAL SPOT
}

Figure 13. Exposed Side of Single Copper Wire Scanned Once

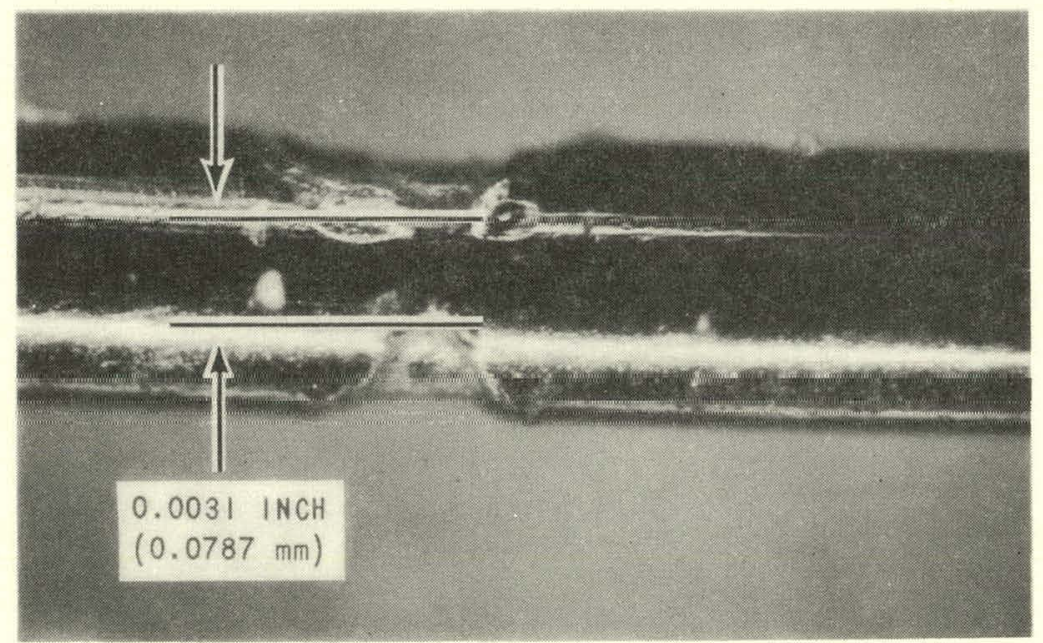

NUMBER 33-AWG COPPER WIRE

6 INCHES/SECOND ( $150 \mathrm{~mm} / \mathrm{SEC})$ SCAN SPEED

50 WATTS LASER OUTPUT POWER

0.005 - INCH-DIAMETER $(0.13 \mathrm{~mm})$ FOCAL SPOT

Figure 14. View Opposite Exposed Side of Single Copper Wire Scanned Once 

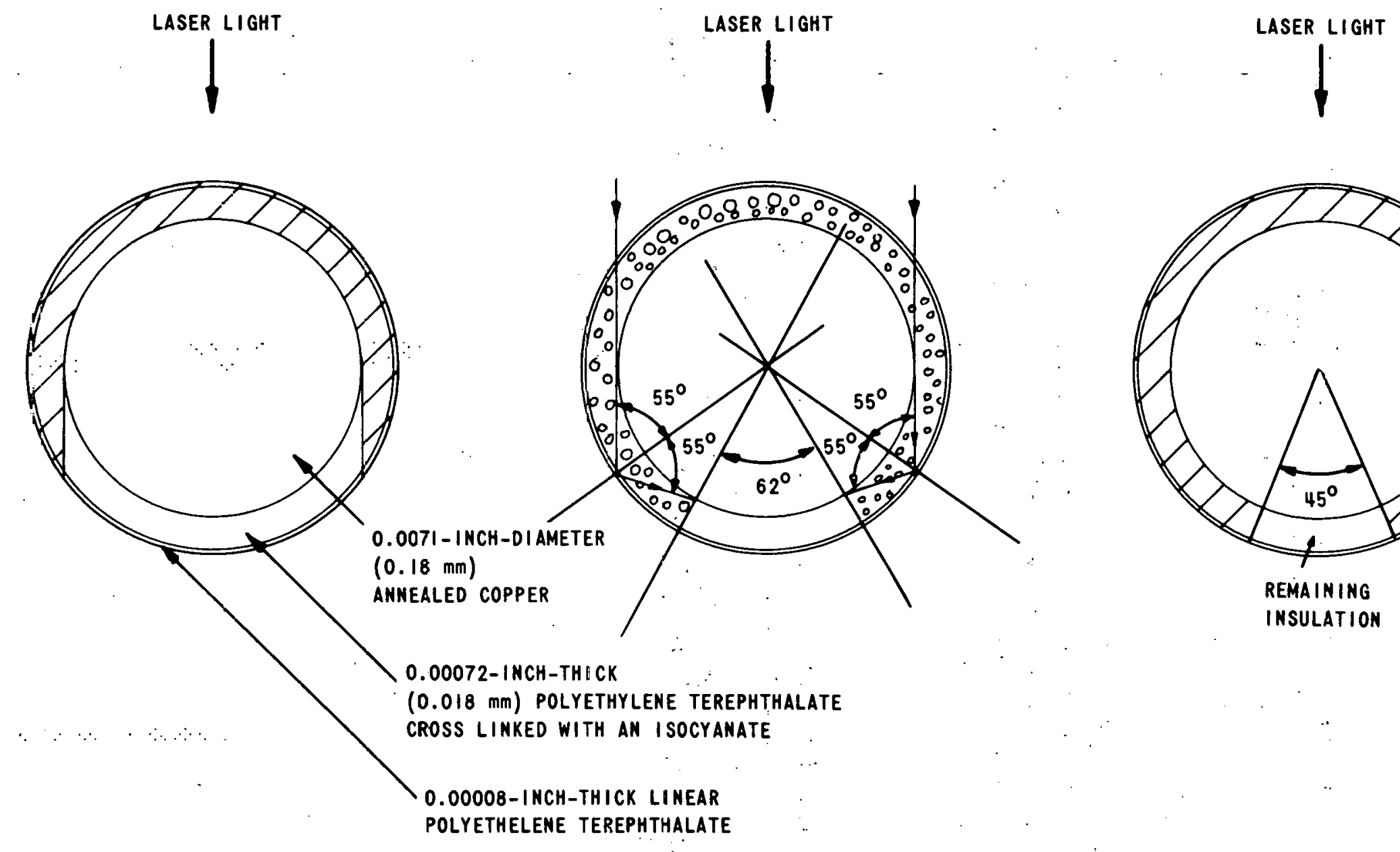

AMOUNT OF INSULATION

AMOUNT OF INSULATION AFFECTED

REMOVED WITH NO INTERNAL

AMOUNT OF INSULATION AFFEC
WITH INTERMAL REFLECTION

AMOUNT OF

REFLECTION

(GEOMETRICALLY DETERMINED)

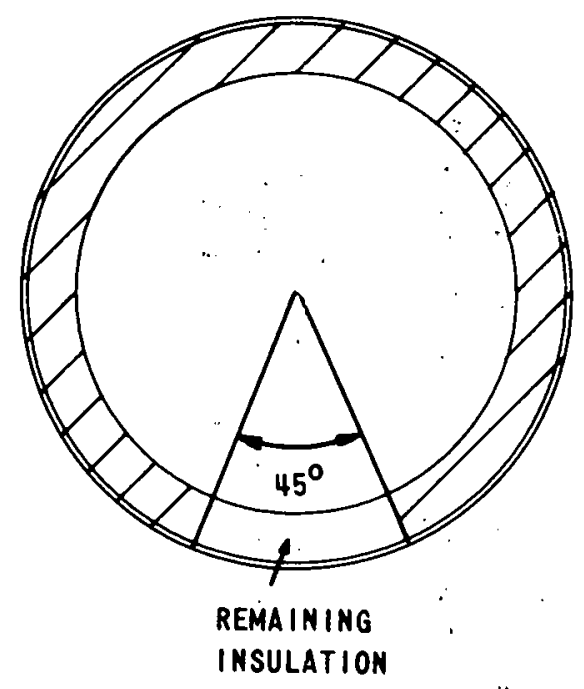

Figure 15. Cross Section of Number 33-AWG Copper Wire and Insulation System, Showing Amount of Insulation Removed 
The pointed shape of the insulation removed due to reflection can be attributed to the low intensity of the focused spot off the exact center of the scan path.

Samples mounted on the drum and rotated at 6 inches/second traverse speed through a focused spot of 0.005 inch diameter and 50 watts $\mathrm{CW}$ output were easily tinned in areas exposed on both sides and on one side.

\section{ACCOMPLISHMENTS}

A process for using the Apollo $\mathrm{CO}_{2}$ laser to remove insulation from multiconductor wire tape has been formulated. Microscopic examinations and tinning attempts have shown single wires can be exposed from one side and reflection internal to the insulation will increase the amount of insulation affected.

\section{FUTURE WORK}

Efforts to develop insulation removal processes capable of handling large amount of wire tape at optimum speeds are continuing. Tooling is being designed that should reduce process time and increase process capability. Use of this tooling will be investigated. A more complete study will be made to determine the advantages of insulation removal by reflection of the laser light within the insulation. 


\section{REFERENCES}

${ }^{1}$ R. T. Horn, Laser Dielectric Removal From Flat Cables (Topical Report), UNCLASSIFIED. Bendix Kansas City: BDX-613-820, March, 1973.

2. Marshall, "Applications a la mode," Laser Focus, Volume 7, April, 1971, pp 26-28.

${ }^{3}$ J. S. Kruger, "Laser Modes--Some Basic Concepts," Electro-Optical Systems Design, Volume 4, September, 1972, pp 12-16. 
THIS PAGE

\section{WAS INTENTIONALLY LEFT BLANK}


R. Bulcock, AEC-KCAO

W. Meyers, LASL

J. Stroud, LLL

C. C. Burks, SLA

R. S. Pinkham, SLA .

D. 'Weingarten, SLA

A. D. Ford, SLL

R. F. Pippert, D/100

W. A. Fogel, D/231

H. T. Barnes, D/534

Copy

J. D. Corey, D/534

L. Stratton, D/534

R. P. Frohmberg, D/800

J. C. Culver, D/812

R. T. Horn, D/812

E. A. Kroencke, D/812

J. D. Alexander, D/834

C. E. Andrews, D/834

D. C. Bruegge, D/834

E. C. Johnson, D/834

C. R. Obenchain, D/834

J. E. O'Hara, D/834

H. F. Darbyshire, D/862

J. R. Ensor, D/862

R. L. Naney, D/862

R. E. Kessler, D/864 